\title{
Konstrukcja i wykorzystanie potrójnego diagramu rozmiaru, ksztaltu i ułożenia ziaren w gabionie
}

\author{
Construction and use of the triple diagram of size, shape and orientation of grains in gabion
}

\author{
Sławomir Bajkowski \\ Katedra Inżynierii Wodnej, Szkoła Główna Gospodarstwa Wiejskiegowwarszawie, slawomir_bajkowski@sggw.pl
}

Zarys treści: $\mathrm{W}$ artykule przedstawiono sposób konstruowania diagramu potrójnego, jak również zasady wydzielenia na jego obszarze pól orientacji, ułożenia oraz kształtu ziaren według przestrzennego układu współrzędnych. Zorientowanie układu XYZ względem boków gabionu i głównego kierunku przepływu wykorzystywane jest w ocenie przepustowości przepuszczalnej części progów gabionowych. Potrójny diagram klasyfikacyjny zawiera trzy elementy identyfikacyjne i umożliwia wprowadzenie wymiarów ziarna, jego kształtu oraz ułożenia względem układu wspólrzędnych: pola trójkątnego układu współrzędnych, którego boki wyznaczają osie XYZ, pola orientacji ziarna w przestrzeni identyfikowanego wymiarami $A, B, C$, pola kategorii kształtu ziaren wyznaczone według bezwymiarowych stosunków $B / A$ i $C / B$.

Słowa kluczowe: ziarno, wymiar, kształt, ułożenie, gabion

\begin{abstract}
The article presents how to construct the triple diagram, as well as the principles of separating in its area the fields of orientation, spatial arrangement and grain shape according to the coordinate system. XYZ system orientation against the gabion sides and the main flow direction is used for estimating the capacity of the permeable part of the gabion sills. Triple classification diagram contains three identification elements and allows to enter the dimensions of the grain, the shape and the orientation against the coordinate system: field of triangular coordinate system which sides are defined by the axes XYZ, field of grain orientation in space identified by the dimensions $A, B, C$, grain shape category field determined by the dimensionless relations $B / A$ and $C / B$.
\end{abstract}

Key words: grain, size, shape, orientation, gabion

\begin{abstract}
Wstęp
Kształt, wielkość i ułożenie luźnego materiału gruboziarnistego w złożu jest efektem długotrwałego procesu począwszy od odspajania przez jego transport do ostatecznego ułożenia. Przemieszczanie się odspojonych ziaren zależy od formy ich kształtu, rodzaju i czasu trwania procesów biorących udział w ich transporcie. Klastyczny materiał denny w środowisku wodnym jest toczony, podrywany przez prądy wznoszące lub spada z wodą z naturalnych nierówności dna lub progów budowli (Chanson 1994, Bajkowski 2010). Transport luźno ułożonych ziaren w wodach rzek i potoków zależy od ich układu oraz oporu, jaki stwarzają. Proces toczenia cechuje ziarna ułożone po-
\end{abstract}

przecznie do nurtu, w układzie tym uzyskuje się najmniejszą siłę niezbędną do obrotu ziarna. Ułożenie poprzeczne powoduje jednak powstanie dużych oporów przepływu. Znaczna część ziaren ustawia się podłużnie względem kierunku przepływu wody, co umożliwia ich przesuwanie ruchem obrotowo posuwistym. W procesie wytwarzania gabionów możemy wpływać zarówno na rodzaj, jak i parametry materiału wypełniającego oraz na układ poszczególnych ziaren (Bajkowski 2013).

Klasyfikacja geometryczna ziaren sedymentu gruboziarnistego prowadzona jest według wymiarów, kształtu oraz ułożenia w złożu (Migoń 2006). W środowisku naturalnym cechy te powiązane są z genezą ich powstawania, intensywnością i czasem trwania procesów sedy- 


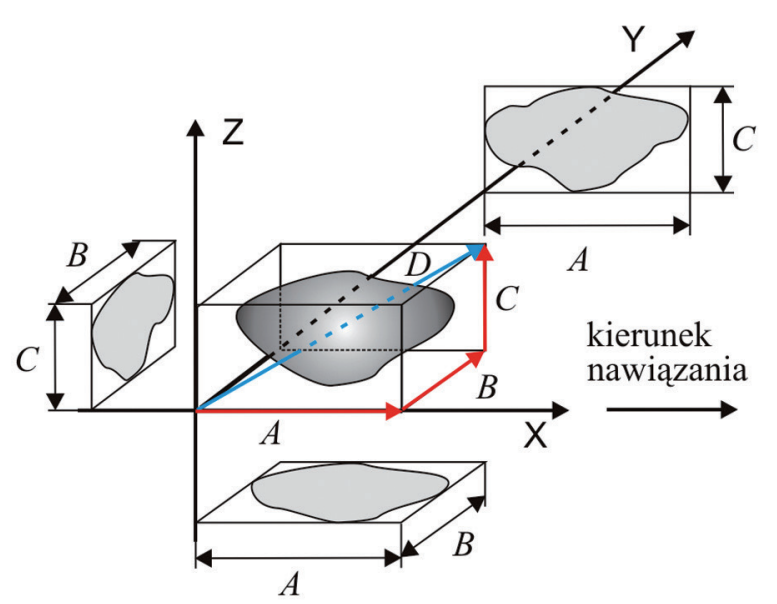

Ryc. 1. Oznaczenie wymiarów ziaren

Fig. 1. Determination of grain size

mentacyjnych oraz oddziaływaniem czynnika wodnego lub wiatrowego (Mycielska-Dowgiałło, Rutkowski 2007). Kategorie kształtu ziaren materiału skalnego gruboziarnistego ustala się według diagramów. Najpopularniejszy jest diagram zaproponowany przez Zingga (1935) i jego późniejsze modyfikacje. $\mathrm{W}$ diagramie tym współrzędne układu podawane są jako bezwymiarowe cechy kształtu uzyskane z wymiarów ziaren $A B C$ wyrażających odpowiednio długość, szerokość i wysokość prostopadłościanu opisanego na bryle ziarna (ryc. 1). Kwadratowy diagram klasyfikacyjny zawiera cztery kategorie kształtu ziaren (sferoidalne, dyskoidalne, elipsoidalne, wrzecionowate), oparte na stosunku wymiarów równym $2 / 3$. Osi odciętych przyporząadkowany jest wskaźnik spłaszczenia ziarna $p_{\mathrm{s}}$ wyrażający stosunek $C / B$, a osi rzędnych wskaźnik wydłużenia $q_{\mathrm{s}}$ równy $B / A$. Dokładniejszy podział kategorii kształtu ziaren wprowadził Powers (1953), uwzględniając stosunek wymiarów równy $1 / 3$, wtedy wyróżnia się dziewięć kategorii kształtu: kuliste, dyskoidalne, płasko dyskoidalne, elipsoidalne, płasko elipsoidalne, płytkowe, cienko płytkowe oraz wrzecionowate i igłowe.

W konstrukcjach gabionowych geometria ziaren wpływa na ustalenie się drogi przepływu w kanalikach utworzonych przez przestrzenie miedzyziarnowe (Olsen, Stokseth 1995, Michioku i in. 2005). Kształt ziaren, wyrażony klasą, jest przyjmowany jako parametr charakteryzujący porowaty ośrodek korpusu (Bajkowski 2006a, Bajkowski, Jastrzębska 2012). Wyraża on również powierzchnie boczną ziaren, która w obszarze czynnego przepływu staje się powierzchnią boczną strumienia płynącego pomiędzy ziarnami (Mohamed 2010). Parametry hydrauliczne powstałej przestrzeni przepływu zależą również od formy ziaren i stanu ich powierzchni bocznej (Fernlund 2005, Bajkowski 2006b).

\section{Konstrukcja diagramu}

Metoda badania materiału ziarnistego zależy od wielkości ziaren oraz celu, jakiemu mają służyć uzyskane parametry. Stosowane są następujące metody badań:
- bezpośrednia - ustalanie wielkości poszczególnych ziaren przeprowadza się w przypadku materiału gruboziarnistego, przy użyciu przymiaru liniowego, polega ono na ustalaniu wymiarów ziarna w układzie sześciennym,

- mikroskopowa - stosowana dla skał zwięzłych w celu ustalenia liczby ziaren w poszczególnych przedziałach wielkości,

- sitowa - przesiewanie ziaren skał luźnych w celu ustalenia rozkładu wielkości ziaren $\mathrm{w}$ procentach wagowych masy ziaren zatrzymanych na skalibrowanych sitach,

- sedymentacyjna - $\mathrm{z}$ wykorzystaniem wag sedymentacyjnych wykorzystujących do oceny wielkości ziaren zależność między ich wielkością a prędkością opadania według prawa Stokesa.

Do ustalenia parametrów kruszywa gruboziarnistego stosowanego w badaniach konstrukcji gabionowych oraz do oceny kruszyw wbudowywanych na obiektach terenowych stosuje się pomiary bezpośrednie. Wyniki uzyskane $\mathrm{z}$ bezpośredniego pomiaru kruszywa gruboziarnistego pozwalają na ustalenie wymaganych charakterystyk materiału. Umożliwiają również przeprowadzenie wnioskowania o charakterystyce materiału według zasad stosowanych $\mathrm{w}$ analizie sitowej.

Potrójny diagram klasyfikacyjny pozwala na identyfikację wymiarów ziarna, jego kształtu oraz ułożenia względem układu współrzędnych (ryc. 2). Diagram zawiera trzy elementy identyfikacyjne:

- pole trójkątnego układu współrzędnych wyznaczone na równobocznym trójkącie, którego poszczególne boki wyznaczają odcinkowe osie XYZ; bezwymiarowe współrzędne $(x, y, z)$ ustala się ze stosunku wartości danej współrzędnej do sumy wszystkich współrzędnych $x+y+z$, pokazane ziarno testowe o wymiarach $258,1 \mathrm{~mm}, 153,3 \mathrm{~mm}, 81,1 \mathrm{~mm}$ (suma wymiarów 492,5 $\mathrm{mm}$ ) w układzie diagramu ma względne współrzędne równe odpowiednio $0,52,0,31,0,16$ (suma współrzęd-

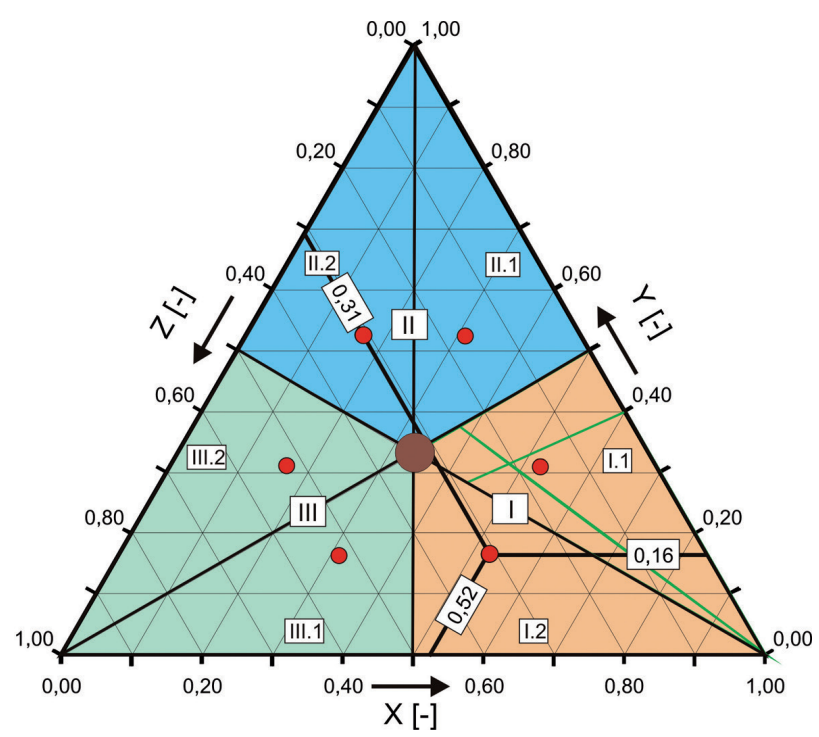

Ryc. 2. Elementy diagramu potrójnego

Fig. 2. Elements of the triple diagram 
Tabela 1. Wymiary, orientacja i ułożenie ziarna testowego

Table 1. Dimensions, orientation and composition of the test grain

\begin{tabular}{cccrrrrrrr}
\hline \multirow{2}{*}{ Orientacja } & \multirow{2}{*}{ Ułożenie } & \multirow{2}{*}{$\begin{array}{c}\text { Schemat } \\
\text { orientacji }\end{array}$} & \multicolumn{3}{c}{ Wymiary ziarna $(\mathrm{mm})$} & \multicolumn{3}{c}{ Współrzędne ziarna } & \multirow{2}{*}{$\begin{array}{c}\text { Schemat } \\
\text { ułożenia }\end{array}$} \\
\hline I I & 1 & I.1 & 258,1 & 153,3 & \multicolumn{1}{c}{$B$} & \multicolumn{1}{c}{ x } & y & z & \\
II & 2 & I.2 & 258,1 & 81,1 & 153,3 & 0,52 & 0,31 & 0,17 & $A B C$ \\
II & 1 & II.1 & 153,3 & 258,1 & 81,1 & 0,31 & 0,17 & 0,31 & $A C B$ \\
II & 2 & II.2 & 81,1 & 258,1 & 153,3 & 0,17 & 0,52 & 0,17 & $B A C$ \\
III & 1 & III.1 & 153,3 & 81,1 & 258,1 & 0,31 & 0,17 & 0,31 & $C A B$ \\
III & 2 & III.2 & 81,1 & 153,3 & 258,1 & 0,17 & 0,31 & 0,52 & $B C A$ \\
\hline
\end{tabular}

nych 1,0); gdy współrzędne diagramu i ziaren wyrazimy w \%, zakres jednostek osi układu będzie zawierał się w przedziale od 0 do 100, a suma współrzędnych wyniesie wtedy 100; wartości współrzędnych wyznaczają położenie ziarna na diagramie oraz pokazują jego orientację i ułożenie przestrzenne;

- pola orientacji ziarna w przestrzeni identyfikowanego wymiarami $A, B, C$, zorientowanego według wymiaru $A$, przedstawiają trzy pola I, II, III; wyznaczają one ułożenie ziarna najdłuższym wymiarem $A$ względem kierunków poszczególnych osi układu XYZ; ułożenie ziarna wymiarami $B$ i $C$ dla każdej z trzech orientacji określają dwa pola; uzyskujemy w ten sposób sześć możliwych położeń ziarna - I1, I2, II1, II2, III1, III2; możliwe położenia testowego ziarna względem układu współrzędnych XYZ podano w tabeli 1 oraz pokazano na diagramie jako punkty wyznaczające poszczególne schematy ułożenia;

- pola kategorii kształtu ziaren wyznaczone według stosunku wymiarów $B / A$ i $C / B$ równego $2 / 3$ na diagramie pokazano dla pola I.1; w ten sposób wyróżnia się cztery pola kategorii kształtu przypisane każdemu z sześciu pól położenia ziaren; wartość wskaźnika spłaszczenia ziarna testowego wynosi $p_{\mathrm{s}}=C / B=0,53$, a wskaźnika wydłużenia $q_{\mathrm{s}}=B / A=0,59$; na diagramie potrójnym graficzny obraz jego współrzędnych układa się w obszarze wyznaczających elipsoidalny kształt ziarna.

\section{Przestrzenna orientacja ziaren}

Ułożenie ziaren osadów rzecznych jest wynikiem oddziaływania na pojedyncze ziarna sił grawitacji i energii przepływu wody, decydujących o ich transporcie i depozycji.
W trakcie przemieszczania się ziarna o zróżnicowanych kształtach przyjmują określone, często najbardziej stabilne orientacje. Gdy rozpatrujemy masowy ruch ziaren rumowiska rzecznego, w tym dużych ziaren ponadwymiarowych, ich układ zależy też od wzajemnego oddziaływania ziaren. Na ich ostateczne ułożenie mają wpływ takie zjawiska, jak toczenie, ale również wzajemne klinowanie się, podparcie oraz zapadanie. Orientacja przestrzenna ziaren ośrodków porowatych jest ważnym elementem wskazującym na kierunek przepływu wody.

Ułożenie ziaren w konstrukcjach przepuszczalnych progów wynika nie tyle z naturalnych oddziaływań wody na ziarna, ile jest zjawiskiem wtórnym, kształtowanym sposobem układania, wbudowywania kruszywa i oddaje przyszłe warunki przepływu. Jest więc wynikiem działalności człowieka, a nie wskaźnikiem przebiegu i intensywności procesów środowiskowych. Układ ziaren w gabionach wynika ze swobodnego spadania poszczególnych ziaren w trakcie ich wypełniania. Zazwyczaj gabiony wypełniamy, wykorzystując sprzęt mechaniczny (ładowarki, koparki). Gdy jednak napełniamy je ręcznie, co zdarza się przy wykonywaniu zewnętrznych warstw konstrukcji oporowych, w większym stopniu możemy ustalać orientację ziaren. W takich warunkach układ ziaren w warstwach zewnętrznych gabionu w dużej mierze zależy od planowanego efektu estetycznego.

Układ ziaren $\mathrm{w}$ gabionie ustalany jest na podstawie orientacji trzech prostopadłych wymiarów ziarna $(A, B$, $C) \mathrm{w}$ stosunku do układu współrzędnych prostokątnych, zorientowanego w kierunku głównego przepływu wody. Układ przestrzenny kruszywa w gabionie charakteryzuje orientacja ziaren (odniesienie najdłuższego wymiaru ziarna $A$ względem kierunków osi układu współrzędnych XYZ) oraz ich ułożenie (odniesienie płaszczyzny wyzna-

Tabela 2. Schemat oznaczania położenia ziaren w korpusie

Table 2. Scheme of the determination position grains in the corps

\begin{tabular}{|c|c|c|c|c|c|c|c|c|}
\hline \multicolumn{2}{|c|}{ Orientacja ziarna } & \multicolumn{2}{|c|}{ Ułożenie ziarna } & Schemat orientacji & \multirow{2}{*}{$\mathrm{X}$} & \multirow[t]{2}{*}{$\mathrm{Y}$} & \multirow[t]{2}{*}{$\mathrm{Z}$} & \multirow[t]{2}{*}{ Schemat ułożenia } \\
\hline \multicolumn{5}{|c|}{ Orientacja ziarna wymiarem $A$ wzdłuż osi X } & & & & \\
\hline \multirow{2}{*}{ I } & \multirow{2}{*}{ podłużna } & 1 & płaskie & $\mathrm{I} .1$ & $A$ & $B$ & $C$ & $A B C$ \\
\hline & & 2 & pionowe & I. 2 & $A$ & $C$ & $B$ & $A C B$ \\
\hline \multicolumn{9}{|c|}{ Orientacja ziarna wymiarem $A$ wzdłuż osi Y } \\
\hline \multirow{2}{*}{ II } & \multirow{2}{*}{ poprzeczna } & 1 & płaskie & II.1 & $B$ & $A$ & $C$ & $B A C$ \\
\hline & & 2 & pionowe & II. 2 & $C$ & $A$ & $B$ & $C A B$ \\
\hline \multicolumn{9}{|c|}{ Orientacja ziarna wymiarem $A$ wzdłuż osi $\mathrm{Z}$} \\
\hline \multirow{2}{*}{ III } & \multirow{2}{*}{ bimodalna } & 1 & wzdłużne & III.1 & $B$ & $C$ & $A$ & $B C A$ \\
\hline & & 2 & prostopadłe & III. 2 & $C$ & $B$ & $A$ & $C B A$ \\
\hline
\end{tabular}


a

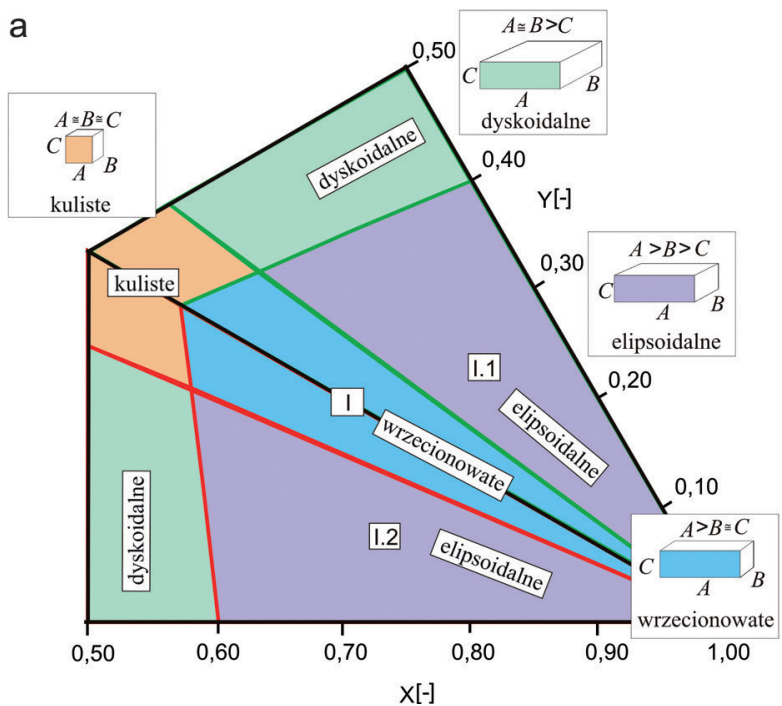

Ryc. 3. Układ pól kategorii kształtu ziaren diagramu potrójnego a-podstawowy, $b$ - zmodyfikowany

Fig. 3. Configuration grain shape category fields of the triple diagram $\mathrm{a}$ - basic, $\mathrm{b}$ - modified

czonej przez wymiary $A$ i $B$ względem płaszczyzn osiowych układu współrzędnych XYZ). Wyróżniamy następujące elementy układu przestrzennego ziaren w strumieniu płynącej wody (tab. 2):

1. Orientacja

- podłużna - gdy ziarna zorientowane są wymiarem $A$ równolegle, wzdłuż głównego kierunku przepływu wody; dla luźnych płaskich ziaren materiału dennego orientacja ta nazywana jest lineacja pradowa, charakteryzującą proces wleczenia rumowiska;

- poprzeczna - gdy ziarna zorientowane są wymiarem $A$ prostopadle do kierunku przepływu; w procesie transportu rumowiska rzecznego orientacja ta charakteryzuje ziarna walcowate $\mathrm{i}$ wrzecionowate toczone oraz ziarna dyskoidalne wleczone po dnie;

- bimodalna - gdy ziarna wymiarem $A$ zorientowane sa pionowo; jest to orientacja niestabilna, która przy działaniu czynnika przepływu może przejść zarówno w orientację podłużną, jak i poprzeczną; orientacja bimodalna charakteryzuje pozorne ułożenie ziaren w strumieniu płynącej wody, wynikające z wzajemnego oddziaływania ziaren, prądów wodnych i pulsacji prędkości przydennych; w transporcie rumowiska dennego charakteryzuje proces unoszenia ziaren.

2. Ułożenie

- płaskie - gdy ziarna umowną płaszczyzną wyznaczoną przez wymiary $A$ i $B$ ułożone są poziomo; w strumieniu płynącej wody poziomo układają się ziarna płaskie zorientowane równolegle (lineacja prądowa) lub prostopadle do kierunku płynącej wody; lineacja prądowa jest najbardziej stabilną pozycją ziaren pod względem oddziaływania na nie strumienia płynącej wody; ziarna ułożone na płask mogą zapadać $\mathrm{w}$ nierównościach dna, szczególnie utworzonego z osadów wysortowanych;

- przypadkowe - gdy ziarna umowną płaszczyzną wy-

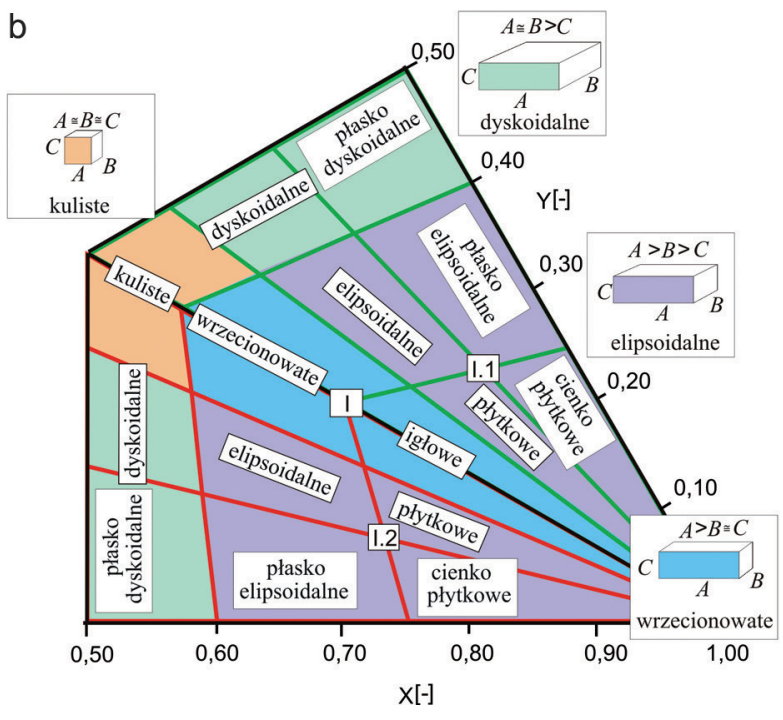

znaczoną przez wymiary $A$ i $B$ ułożone są pionowo; ułożenie przypadkowe dotyczy ziaren dowolnie zorientowanych; dla orientacji podłużnej i poprzecznej ziarna, przypadkowe ułożenie jest pionowe; gdy ziarna zorientowane są bimodalnie, ułożenie jest wzdhużne lub prostopadte; ułożenie przypadkowe jest niestabilne (pozorne) i cechuje je duża dynamika zmian; gdy ziarna nie mają dodatkowych punktów podparcia, układają się na płask lub pozostają nachylone, podparte na innych ziarnach.

Ziarno kruszywa opisane wymiarami $A, B$ i $C$ może być wbudowane w korpus długością $A$ odpowiednio wzdłuż osi X, Y lub Z. Na rycinie 1 pokazano pojedyncze testowe ziarno kruszywa ułożone płasko, podłużnie względem kierunku nawiązania; inne warianty ułożenia zestawiono $\mathrm{w}$ tabeli 2 . Za kierunek nawiązania ukła-

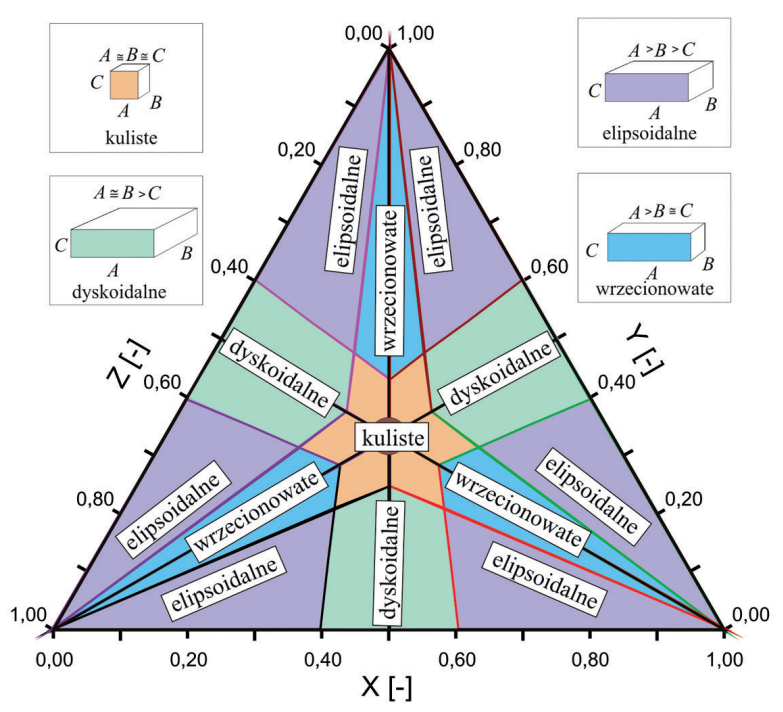

Ryc. 4. Potrójny diagram wymiarów, ułożenia i kształtu Fig. 4. Triple diagram dimensions, orientation and shape 
du współrzędnych przyjęto główny kierunek przepływu wody w korpusie, orientując według niego kierunek osi $\mathrm{X}$. Na rycinie 2 pokazano ziarno testowe w sześciu możliwych sytuacjach przestrzennego wbudowania w korpus progu gabionowego według tabeli 1 .

\section{Kategorie ksztaltu ziaren}

W każde z sześciu pól ułożenia wprowadzono podziały kategorii kształtu transformowane na układ współrzędnych trójkątnych z diagramu kwadratowego. Na rycinie 3 pokazano dwa pola kategorii kształtu na części diagramu odpowiadającej podłużnej orientacji ziarna. Granice poszczególnych czterech kategorii kształtu ustalone według wartości wskaźnika spłaszczenia ziarna $p_{\mathrm{s}}$ oraz wskaźnika wydłużenia $q_{\mathrm{s}}$ równych $2 / 3$ pokazano na ryc. $3 \mathrm{a}$. Zmodyfikowaną wersję diagramu z podziałem na 9 kategorii kształtu według wskaźników równych $1 / 3$ przedstawiono na rycinie $3 b$. Pełny diagram potrójny w wersji z czterema kategoriami kształtu pokazano na rycinie 4 .

\section{Sposób wykorzystania diagramu}

Pierwszym zasadniczym i niezbędnym etapem wykorzystania zaproponowanego diagramu jest wykonanie przestrzennych pomiarów ziaren kruszywa. Pomiaru można dokonać metodą bezpośrednią, optoelektroniczną lub laserową. W wyniku tych pomiarów uzyskujemy długość $A$, szerokość $B$ i wysokość $\mathrm{C}$ ziarna. Wbudowując ziarno w korpus progu, należy oznaczyć jego ułożenie według tabeli 2. Schemat ułożenia odnosimy do schematu orientacji odpowiednim przypisaniem wymiarów $A, B, C$ współrzędnym $x, y, z$. Nanosząc wartości współrzędnych ziarna na szablon diagramu, identyfikujemy punkt odpowiadający jego cechom geometrycznym, orientacji, ułożeniu oraz kategorii kształtu. Wykorzystując programy graficzne umożliwiające wykonywanie wykresów trójkątnych, wymiary ziarna wprowadzamy bezpośrednio do programu (Grapher 2002). Na współrzędne bezwymiarowe są one transformowane $\mathrm{w}$ arkuszu edytora. W takim przypadku należy opracować szablon wykresu trójkątnego zawierający 4 lub 9 kategorii kształtu, według jednego z zaproponowanych schematów na rycinie 3 .

\section{Podsumowanie}

Kategorie kształtu ziaren kruszywa określa się, wykorzystując kwadratowy diagram Zingga (1935), jego późniejsze modyfikacje lub zaproponowany diagram potrójny. Wprowadzając w pole diagramu potrójnego względne wymiary, określa się kategorie kształtu oraz orientację i ułożenie ziaren w złożu lub korpusie progu przepuszczalnego. Położenie punktów charakteryzujących wymiary ziarna na trójkątnym diagramie potrójnym pozwala zdefiniować klasy ułożenia jako parametru opisującego warunki prze- pływu w korpusie. Wymiary ziaren kruszyw gruboziarnistych określa się metodą bezpośrednią, jak też nowymi metodami pomiaru trójwymiarowego, optoelektroniczną lub laserową. W metodzie bezpośredniej ustalane są zazwyczaj trzy podstawowe wymiary ziaren: $A$ - długość ziarna, wymiar lub średnica największa, $B$ - szerokość ziarna, wymiar lub średnica pośrednia, $C$ - grubość ziarna, wymiar lub średnica najkrótsza.

$\mathrm{Na}$ diagramie wydzielone są pola klasyfikacyjne kategorii kształtu ziaren, na których wprowadzono linie podziału na poszczególne kategorie kształtu ziaren, uzyskując $\mathrm{w}$ ten sposób obszary przypisane poszczególnym kategoriom. Obszary te tworzą promienisty układ pól klasyfikacyjnych ułożonych symetrycznie względem odcinków łączących naroża wykresu z jego środkiem (dwusieczne wewnętrznych kątów narożnych diagramu). Punkt środkowy diagramu odwzorowuje ziarno kuliste $A \cong B \cong$ $C$, punkty narożne - ziarna igłowe (nitkowate) $\left(A_{\rightarrow \infty}, B_{\rightarrow \circ}\right.$, $C_{\rightarrow 0}$ ) ułożone wymiarem $A$ odpowiednio wzdłuż poszczególnych osi układu.

\section{Podziękowania}

Autor dziękuje anonimowemu recenzentowi za uwagi do artykułu.

\section{Literatura}

Bajkowski S., 2006b. Przewody filtracyjne przepustów. W: S. Kostecki (red.), Monografia problemy hydrotechniki. Modelowanie i hydroinformatyka oraz wybrane zagadnienia ochrony przeciwpowodziowej. Dolnośląskie Wydawnictwo Edukacyjne, Wrocław: 145-153.

Bajkowski S., 2006a. Rozdział przepływu na przelewie gabionowym. Przegląd Naukowy Inżynieria i Kształtowanie Środowiska 2(34): 113-120.

Bajkowski S., 2010. Sediment segregation on weirs of lowland rivers. Annals of Warsaw University of Life Sciences SGGW 42(1): 177185.

Bajkowski S., 2013. Warunki przepływu wody przez budowle przepuszczalne. Monografia 341. Wydawnictwo SGGW: 151.

Bajkowski S., Jastrzębska U., 2012. Badanie wpływu kształtu progu gabionowego na podział przepływu. Przegląd Naukowy Inżynieria i Kształtowanie Środowiska 21/4(58): 263-272.

Chanson H., 1994. Hydraulic Design of Stepped Cascades, Channels, Weirs, and Spillways. Pergamon, Oxford, OX, England and Tarrytown, NY, USA: 261.

Fernlund J.M.R., 2005. Image analysis method for determining 3-D shape of coarse aggregate. Cement and Concrete Research 35(8): 1629-1637.

Grapher, 2002. Grapher Version 4.01. User's Guide. Golden Software Inc., USA.

Michioku K., Maeno S., Furusawa T., Haneda M., 2005. Discharge Trough a Permeable Rubble Mound Weir. Journal of Hydraulic Engineering 131(1): 1-10.

Migoń P., 2006. Geomorfologia. Wydawnictwo Naukowe PWN, Warszawa: 460.

Mohamed H., 2010. Flow over Gabion Weirs. Journal of the Irrigation and Drainage Engineering 136(8): 573-577.

Mycielska-Dowgiałło E., Rutkowski J., 2007. Badania cech tekstualnych osadów czwartorzędowych i wybrane metody oznaczania ich wieku. Wydawnictwo Szkoły Wyższej Przymierza Rodzin, Warszawa: 278 . 
Olsen N.R.B., Stokseth S., 1995. Three-dimensional Numerical Modelling of Water Flow in a River with Large Bed Roughness. Journal of Hydraulic Research 33(4): 571-581.

Powers M.C., 1953. A New Roundness Scale for Sedimentary Particles. Journal of Sedimentary Petrology 23: 117-119.
Zingg T.H., 1935. Beitrage zur schotteranalyse. Schweizerische Mineralogische und Petrographische Mitteilungen. Swiss Bulletin of Mineralogy and Petrology 15: 38-139. 